\title{
FORUM
}

\section{THE 2014 GAZA WAR AND THE ELUSIVE PEACE IN PALESTINE}

\author{
ANTHONY OBERSCHALL ${ }^{l}$
}

\begin{abstract}
Neither Hamas nor Israel pay the cost of their episodic Gaza wars. Israel gets weapons and funds from the U.S. government and from the American Jewish community. Hamas gets weapons, funds and reconstruction funds from Iran, Qatar, and the international humanitarian community; i.e. the U.S., UK, EU, and Nordic states via the UN agencies they fund. Israel's Gaza blockade has since 2007 allowed more than a hundred truckloads of food and humanitarian aid a week into Gaza, even during times of fighting. Israel has curtailed dual-use goods like cement and pipes which Hamas diverted for war purposes. In 2014, as previously, both sides repeatedly violated the Geneva Convention. To stop repetition of the Gaza wars, outsider financing for the adversaries has to be reduced and weapons must be removed and banned from Gaza. Gaza should be demilitarized in a "weapons-to-end-the-blockade" cease-fire deal. Israel should pay rent to the Palestine Authority for West Bank settlements, access roads, military bases and other occupied real estate. Suggestions are made in this paper about how to accomplish this goal.
\end{abstract}

KEYWORDS Gaza war, Hamas, Israeli Defense Force, Gaza blockade, humanitarian aid, Geneva Conventions, demilitarization, two state solution

In the aftermath of the 2014 Gaza war, what steps by the stakeholders - the Palestinians, Israel, Egypt, the U.S., humanitarian agencies, the international community - will make a lasting cease fire likely, and yield eventual negotiations for peace in Palestine? How is it possible to prevent the adversaries from starting yet another war in Gaza one or two years from now, as has happened in the past? To unravel this puzzle it is necessary to start by examining the 2014 Gaza war itself, its causes, its course, its outcome. It makes no sense for outside stakeholders and humanitarian agencies to finance

1 Anthony Oberschall is retired professor of the University of North Carolina; e-mail: tonob@ live.unc.edu 
the reconstruction of Gaza and enable the rearming of Hamas and other Palestinian fighters so they can wage another destructive and inconclusive war with Israel in two years' time. Nor should maintaining the status quo in Gaza be Israel's goal. So far, Gazan wars have ended when Hamas runs out of rockets and weapons and when Israel has destroyed the tunnels that threaten nearby Israeli settlements and inflicts punishment that it believes will deter Hamas. Surely one can do better. I will examine the chances for a "weaponsto-end-the-blockade" deal after reviewing the situation in Gaza and the war.

\section{THE BLOCKADE}

Hamas demands an end to the Israeli-Egyptian "blockade", also referred to as a "siege", but the media discourse on Gaza has misrepresented the "blockade." According to the dictionary, a blockade refers to the sealing up of a place by hostile troops to prevent entrance and exit. In pre-modern warfare, like the siege of Vienna by the Turks, a siege was used against fortified enemy strongholds to starve the defendants, including non-combatants, until they surrendered. In twentieth century wars, like World War I where naval forces and submarines blockaded entire countries, or the siege of Leningrad in World War II, the goal was also to starve entire populations and the adversary into submission. That is not what the Gaza blockade is about: hundreds of truckloads of food and medical supplies daily transit the crossings from Israel to Gaza, and more food and consumer goods transit through tunnels from Egypt. During 2014, the Israeli Defense Force (IDF) transferred between 300 and 1200 truckloads of goods a month to Gaza: mostly food, medicines and humanitarian aid [IDF, Operation Protective Edge by the numbers, 8/5/14]. As two reporters noted, "There are plenty of things to buy in Gaza: goods are brought over the border or are smuggled through tunnels with Egypt... The issue is not hunger. It is idleness, uncertainty and despair" [NYT, 7/14/10]. Israel limits dual-use goods such as cement and pipes that are used by Hamas for warfare. However, to avoid confusion, I shall refer to the limitations placed on the movement of goods to Gaza from Israel and Egypt as a blockade.

The checkered story of the blockade starts after the unilateral Israeli withdrawal from Gaza in September 2005. An Agreement on Movement and Access was negotiated between Israel, Egypt, and the Palestinian Authority. The purpose was to prevent arms, explosives and terrorists getting in and out of Gaza but to allow imports of food, animal fodder and medical supplies (referred to as humanitarian aid) construction materials (gravel, cement, etc.) and other items, and the export of agriculture crops, industrial goods 
(especially clothing), all of it estimated at 1500-2000 truckloads a month, to travel through crossings from Israel to Gaza. In addition, agreements were made about the transmission of electricity, diesel fuel and natural gas through pipelines.

On January 26, 2006, Hamas won the legislative elections in Gaza. Rocket and mortar fire from Gaza to Israel soon doubled, from 417 incidences in 2005 to 968 in 2006 [Israel Security Agency, monthly reports], as did tit-for-tat retaliatory Israeli airstrikes. Palestinian fighters repeatedly attacked crossings (January 15 at Karni, February 21 near Karni) and Israel closed crossings for days or reduced traffic, allowing through only humanitarian shipments. The largest shutdown occurred in June 2006 when Palestinian fighters tunneled under the Gaza perimeter fence and captured an Israeli soldier. The IDF then undertook the first major ground operations into Gaza (Operation Summer Rains) since unilateral disengagement. The operation ended with a ceasefire and truce in November 26, 2006. Hamas continued to smuggle weapons and rockets into Gaza from the Egyptian border through tunnels.

This pattern of Hamas rocket attacks and Israeli retaliation with border closings and air strikes and IDF invasions, followed by a ceasefire, resumption of shipment of goods (in addition to humanitarian supplies which continued during the hostilities), followed by a temporary lull in Palestinian attacks, and then a gradual increase in the firing of rockets and the predictable Israeli response, has been repeated several times since 2006. In June 2007, Hamas seized power from Fatah in Gaza by force during a Palestinian mini-civil war in which about 160 were killed and 700 wounded, each charging the other with torture and with murder of prisoners [Time, 2/7/09]. Rocket attacks on Israel increased to 783 in 2007 and to 1730 in 2008. Israel limited shipments of goods to humanitarian items (e.g. in December 2007, 1278 truckloads of food products for human consumption, 265 for animal feed, 45 of medical supplies, and a few other truckloads). After another truce in June 2008, Israel lifted the ban on shipments to Gaza and the normal flow of goods resumed (e.g. July 2008, food products for human consumption numbered 1635 truckloads, animal feed 343, medical supplies 34, but also construction materials 2256 truckloads, in addition to other truckloads of industrial/electrical and nonedible consumer goods) [data from reports of the UN Office for Coordination of Humanitarian Affairs, Occupied Palestinian Territories, Gaza Crossing and Paltrade]. Hamas decreased the number of rocket and mortar attacks from five hundred incidences a month to five in July through October. The truce broke down in November when rockets were fired 193 times and Israel imposed another goods blockade, mounted air strikes and the IDF invaded Gaza to destroy the Hamas rocket teams. 
The periodic closings of the border have had a devastating effect on the Gazan economy. Food shipments and medical supplies have kept the Gazans alive, but agriculture and manufacturing have been devastated. According to the World Bank [Investing in Palestinian Economic Reform and Development, Paris, Dec. 17, 2007; West Bank and Gaza, various updates; UN Office for the Coordination of Humanitarian Affairs, various reports ], forty thousand jobs were lost in agriculture and fishing, and much of the garment industry was shuttered with the loss of thousands of jobs. Seventy percent of farm land was no longer irrigated. Israel reduced shipments of industrial fuels, pipes and construction materials, which reduced the generation of electricity and degraded the water and sanitation system. Israel reduced these imports because Hamas and its allies were diverting these materials (so-called 'dualuse' materials like cement and pipes) to make rockets and explosives and build tunnels (e.g. fertilizer may be converted to explosives).

The Islamic Resistance Movement 's (Hamas') charter says that "Israel will exist and continue to exist until Islam obliterates it...the Islamic Resistance Movement believes the land of Palestine is an Islamic Waqf (religious trust area) consecrated for future Muslim generations until Judgment Day...There is no solution to the Palestine question except through jihad; initiatives, proposals, and international conferences are all a waste of time and vain endeavors... The Jihad for the liberation of Palestine is an individual obligation...Death for the cause of Allah is Hamas' most sublime belief" [paragraphs $8,11,13,15$ ]. The lifting of the blockade by Israel and the revival of the Gazan economy depends on the will of Hamas to stop attacking Israel once and for all, but Hamas keeps choosing military confrontation with Israel over the welfare of the Gazan population, in accordance with its ideology and charter.

Gaza makes up the shortage of consumer goods and dual-use goods induced by the blockade by importing through some 200 Rafah tunnels to Egypt - Oxfam estimates that $47 \%$ of civilian goods transit to Gaza in the tunnels [Oxfam, Briefing Note, 6 Dec 2012]. According to Steve Erlanger [NYT, 1/1/09] who interviewed Gazan merchants, the tunnel goods include "cigarettes and snacks, like the popular Egyptian potato chips called Chipsy and Crunchy, as well as larger products like generators, television and washing machines, sheep and goats, even automobiles". The tunnel traffic is heavily taxed by Hamas and is an important source of the movement's revenue. In addition, rockets, weapons and explosives used by Hamas and its associated fighters (Islamic Jihad) transit through the tunnels.

The current 2014 "blockade" crisis was not due to Israel reducing shipments, but to Egypt closing and destroying many of the Rafah tunnels; 
some were flooded with sewage. Egypt claims that Hamas had shipped weapons and fighters to the Sinai insurgents who have been battling the Egyptian government. Since the start of 2014, 21,704 truckloads containing 536,481 tons of goods entered Gaza from Israel. In the week of June 29 to July 5, 2014, 1366 trucks carrying 32,700 tons of goods entered Gaza at the Kerem Shalom freight terminal crossing, about half of it food [IDF-COGAT, Details of movement in Gaza crossings, various dates]. Photos on the internet show long lines of trucks waiting to be processed through the crossing. The Palestinian claim and media narratives about Israel tightening the blockade before the latest Hamas rocket attacks in July is not supported by the data about shipments from Israel to Gaza.

There is no shortage of food and medicine in Gaza, even during the current fighting. An Op/Ed in the New York Times (NYT) on 8/5/14 by a Palestinian writer "Gaza: a Wartime Diary" describes the impact of the blockade on his family. The entry for July 28 , during a cease-fire, reads: "the market was full of people buying clothes. A few shops were open selling sweets and chocolates...we fry the fish this morning, but we have no bread to eat with it...My father-in-law sets off on his bike to the bakery....and he returns , after less than an hour in line, laden with warm loaves... The electricity is out again. Everything in the fridge has to be thrown out: meat, chicken, even vegetables...The electricity comes on about 1:30 am...All the kids plug in their cellphones to charge them. I plug in my laptop..." The Gaza war is terrible, and the child and civilian casualties are horrible, but the situation isn't comparable to the sieges of Leningrad, Warsaw, and Budapest in World War II. Civilian casualties then were in the tens of thousands. People didn't have any meat, chicken and vegetables to throw out. They had to melt snow for water and carve up dead horses in their neighborhood. Some got killed while foraging for food. A major problem was finding coal and wood for furnaces so that building residents wouldn't freeze to death [for Budapest, cf. Deak 2005].

The AMA also covered the movement of persons as well as goods. Before the start of the 2000 (Al Aqsa) intifada, more than twenty thousand Gazans crossed daily to Israel, some to work in Israel and some to the West Bank. During the intifada Israel reduced the number of exit permits drastically for security reasons; i.e. to stop fighters and terrorists from joining the West Bank insurgents. Since then, the Israelis have restricted exits to medical emergencies and for family reasons (funerals, weddings) but only to first degree relatives. In 2013 there were 4760 exits per month, about one third of them for patients and their companions, one third for merchants, and one third for others, e.g. family [Gish-Legal Center for Freedom of Movement, Exits 
from Palestine to Israel, Erez Crossing, Gaza Access and Movement, 2013 Summary]. The demand for travel to and from the West Bank and to Jordan is many times greater. Most Palestinians have close family and relatives across these borders and Palestinians have professional, educational and other travel needs. The Palestinians have charged that Israeli travel restrictions amount to collective punishment intended to keep them imprisoned in Gaza. Restrictions on movement are a major grievance for Gazans. For the Israelis, control of Palestinian population movement and the walls - the separation wall in the West Bank and the fence in Gaza - are necessary security measures for preventing attacks. The movement of people in and out of Gaza will be high on the agenda for negotiations about a permanent end to hostilities.

The Egyptian government has also drastically reduced Gaza travel in 2013 for security reasons; i.e. to prevent Hamas offering support to Sinai insurgents. The numbers using the Rafah exit fluctuated from 11,000 to 4,000 monthly Palestinian crossings, then from July to December 2013 it declined to less than one thousand a month [Gish-Legal Center, op.cit]. Thus it is on the Egyptian side, rather than the Israeli side, that the restrictions on movement in 2014 for both goods and persons have impacted Gaza the most.

\section{THE GAZAN ECONOMY}

Gaza has three economies, all of them supported and subsidized by outside stakeholders, states, international agencies like UNWRA, humanitarian NGOs, Islamic foundations, World Food, World Health, US, EU, Gulf states, Saudis, Iran, donations and gifts of all types, Palestinians' remittances, etc. The Palestinians are the world's largest per capita recipients of outside donor funding, especially the Gazan population. In some ways all this outsider aid has provided for the well-being of the people of Gaza. Life expectancy for Palestinians is 73 years, about the same as Jordan, a little higher than Egypt, and much higher than Pakistan (66) and the Russian Federation (68); infant mortality is 19 per 1000 live births, about the same as Jordan and Egypt; the proportion of births attended by skilled medical staff is $99 \%$ [data.worldbank. org/country/west-bank-and-gaza]. In 2006, 12\% of Gazans rated economic conditions as good or very good; in December 2012, 49\% rated them good or very good [Arab Barometer public opinion surveys, Washington Post, 8/4/14]. In a deeper sense, the international welfare dependency of those defined as "refugees" has led to failed outcomes; Palestinian leaders, be they Hamas or Fatah, are not constrained by a sense of responsibility for many West Bank and Gaza inhabitants. If Hamas had to raise revenues from economic activity 
in Gaza to govern, rather than receiving and looting outside donations and services, it might well moderate its policies and rocket attacks on Israel.

The first Gazan economy is the "humanitarian" economy. Oxfam reported that there were 1.1 million persons in Gaza (out of $1.7 \mathrm{~m}$ ) on food aid. Direct food assistance went to 150,000 families with 800,000 members; the others were financed by emergency aid and UNRWA was running 221 schools with 210,000 school children in grades 1-9, and spent $\$ 160$ million in 2012 on education, mostly obtained from the U.S., the EU, the UK, and the Nordic states. It had ten thousand staff, almost all Palestinians. It ran construction projects worth $\$ 65$ million and employed fourteen thousand (full time equivalent) workers. For these projects, it imported 12,426 truckloads of construction materials through Israeli crossings [UN. Report of the Commissioner General of the UN Relief and Works Agency for Palestinian Refugees in the Near East, 1 January - 31 December, 2012] Other agencies employ many Palestinians and distribute goods and provide services. Hospitals, clinics and medical services are provided by international agencies. UNWRA health care facilities cared for about one hundred thousand pregnant women who accounted for $78 \%$ of births in Gaza. The annual reports of UN, international NGOs and other agencies in Gaza provide details about what they spend on and the size of their staffs.

The second economy is the "tunnel" economy. Portland Trust (UK) [Palestine Economic Bulletin, various issues] estimates the value of the underground flow of consumer goods, fuel, construction materials, weapons, cigarettes, etc. at $\$ 700$ million/year. Hamas taxes these goods, charges fees and issues permits and licenses. Hamas uses these revenues for weapons, the salaries of fighters, payments to widows and orphans of fighters, the reconstruction of destroyed houses, etc. Hamas employs several thousand adolescents and young men to dig the tunnels and move goods through them, and it pays them well. One smuggler said in an interview "You have 25,000 kids who have no work, so they go work in the tunnels... unemployed young men earn $\$ 100$ for each meter they dig" [NYT, 1/24/09].

The third economy is what elsewhere in the world is known as the first economy: i.e. commerce, transport, agriculture, construction and public services. It is this economy that has collapsed since the AMA agreement of 2005 due to the Hamas rocket attacks and the Israeli retaliation - limits on goods and limits on traffic in people. No one claims that Gaza could be another Singapore or Hong Kong. Nevertheless, its economy, especially its agricultural exports and manufacturing, were doing well before the cycle of violence started in 2006. For the sake of attacking Israel with rockets and fighters, Hamas repeatedly provoked the temporary Israeli border closings, 
knowing that it would cost the normal Gazan economy thousands of jobs.

The official Gaza budget is $\$ 900$ million, paid for mostly by international donors for public work, police and courts, education and health services (for those not in the "humanitarian" refugee economy). Hamas has a predatory stranglehold on sources of revenue in Gaza, on the humanitarian economy, on the tunnel economy, and on the normal economy. One third is syphoned off by Hamas for its security forces and rocket brigades. Goods from international agencies such as food and construction materials get appropriated for tunnel construction and feeding supporters and fighters who are not eligible for humanitarian aid. It is estimated that Hamas appropriates one-half of all public sector employees' salaries (Levitt 2006).

\section{THE WAR}

In a conventional war, treaties and conventions (Geneva Conventions) bind adversaries and are symmetrical and reciprocal, as in the treatment of prisoners and the protection of civilians. Both sides benefit from compliance. In unconventional war, insurgents against a state, there is no such symmetry and reciprocity (Kaldor 2001). The insurgents don't believe they have a chance of successfully fighting within the norms defined by the laws of war against a powerful adversary. The insurgents' goal is to make the conflict so costly that the adversary will eventually give up, make unilateral concessions, and opt for a political solution. The insurgents' use of violence is tactical rather than principled. Violence is directed not only against the adversary but against moderates and bystanders not committed to the insurgency who are intimidated, and who are at times executed as "traitors" and "collaborators."

The Geneva Conventions are binding on insurgents as well as states (Gutman and Rief 1999). The Conventions protect civilians in war and affirm the rights of combatants. They ban targeting of civilians, torture, hostage taking, the use of human shields, summary executions, deportation, and the wanton destruction of property. They limit modes of warfare that put civilians at risk unnecessarily, such as excessive collateral civilian damage in military operations, and they require a proportionate response against armed attack in order to limit civilian casualties. Combatants, whether members of an army or insurgents, must wear a uniform or other visible identifying markers, carry arms openly, and must be subject to an organization that enforces compliance with the rules of war.

Clandestine organizations not only have combatants but also helpers who hide weapons and combatants, who transport, manufacture, finance, act as 
lookouts, spy and inform; i.e. constitute an infrastructure of insurgency which may be larger than the network of active fighters. Whether these supporters and resources should be defined as civilian or combatant and should be accorded protection as civilians has been contested (Anderson 2003). Governments have argued that strict adherence to the laws of war framework in these cases jeopardizes military success and fails to provide adequate protection for the civilian population because combatants and civilians are not sufficiently distinguishable. For instance, a truck repair shop and its employees could also be making rockets, with the same facilities, materiel and tools. If an Israeli airstrike destroys the workshop and kills employees, the Israelis may claim it was a legitimate target and the employees were combatants. Hamas on the other hand will count it as another civilian building strike, and consider the employees to be civilian casualties.

In the Gaza fighting, the Geneva Conventions are binding on insurgents as well as states. Using non-combatants to shield, place or protect military weapons like rockets and mortars, and targeting civilians with rockets, as Hamas is doing, are war crimes. In response to IDF aerial photos of rocket launch sites adjacent to a schools and civilian houses, a senior Hamas official said that Hamas "fighters had no choice but to use residential areas from which to launch missiles " [Daily Mail online, 9/12/14]. Israel and the IDF are bound to "proportionality" in their responses and to limit "collateral damage." Those are vague and disputed criteria in urban warfare amid densely-packed civilians. In other urban warfare (the Battle of Algiers in the Algerian war of independence, the siege of Budapest in 1944-45, the siege of Aleppo in the current Syrian civil war, the siege of Grozny in the Chechnya war, the siege of Hue in the Vietnam war....) the adversaries have been responsible for thousands of civilian deaths and thousands of destroyed buildings. A historian once observed about the Budapest siege that casualties would be high "if the defenders are willing to sacrifice both the population and themselves" (Deak 2005), a statement which also accurately describes the war in Gaza.

Media coverage of the war was itself a war, a propaganda war. Hamas restricted international media coverage to images and narratives about civilian victims and threatened reporters who would not comply. This meant that media coverage was restricted to, for example, emergency room scenes with child casualties being rushed into the hospital and mothers of dead sons, surrounded by crowds, proudly reporting that they died as "martyrs." Hamas was threatening reporters in Gaza. Journalists from around the world reporting seeing rockets fired from civilian areas in Gaza received threatening tweets,.e.g. "in World War II spies got shot" [Jerusalem Post 7/29/14]. During the August ceasefires, reporters had an opportunity to speak 
privately to Gazans one to one and different sentiments surfaced. One Gazan complained: "So far nothing has been achieved...Fatah, Hamas, Israel are parties. We are people. We are victims. If these parties have differences, why do we pay the price...?" [NYT, 8/11/14].

I do not believe that, in unconventional warfare like the Gaza wars, the IDF ought to be held to a higher standard than armies in World War II, and that Hamas be held to a lower standard. I do not believe in imposing a double standard on warfare, one for armies and one for insurgents. In the words of the military law expert Kenneth Anderson [op.cit. 2003, p43], the humanitarian critiques of the conduct of the Gaza war "risk in the end creating a law of war that assumes, for all practical purposes, that the burden is on one side, the side of the more advanced technology and the less desperate military...A form of warfare that tacitly assumes, indeed permits, that the weaker side must fight by using systematic violations of the law... This is unsustainable as a basis for the law of war."

In my judgment, to bomb a building inhabited by civilians because a Hamas leader is living there is a disproportionate response (especially since he is most likely in a tunnel somewhere else); on the other hand, if there is a weapons store and factory in an inhabited building or tunnel underneath or in a mosque, they are legitimate military targets so long as the inhabitants are given a warning to leave, which the IDF does. The use of mortars, an imprecise weapon, by both Hamas and the IDF in a densely-inhabited city looks to me like a violation of the principle of limiting collateral damage.

A full non-partisan investigation should be conducted into war crimes allegations, but it is not likely to happen. After the 2009 Gaza war, the UN Human Rights Council (UNHRC) appointed a fact-finding mission to investigate possible war crimes, crimes against humanity, and violations of international humanitarian law. Because the UNHRC had a record of proPalestinian and anti-Israel partisanship, to be credible the mission needed an internationally-respected chairperson. The South African judge Richard Goldstone, himself a Jew, but more importantly, a prominent judge for the South African Truth and Reconciliation Commission and lead prosecutor in the International Criminal Tribunal for the Former Yugoslavia, agreed to serve, but only if both adversaries, the IDF and Hamas, were investigated. The investigation turned out to be disaster. The mission selected only 36 of several hundred incidents for investigation, and admitted (UN Fact Finding Mission on the Gaza Conflict, Sept. 2, 2009, paragraph 25) that it did not "pretend to reach the standard of proof applicable in a criminal trial." Neither the Israeli government nor Hamas and other Palestinian fighter groups cooperated with the investigation (paragraph 441) Witnesses were fearful about testifying 
because of potential reprisals from militants. The mission had to rely on "indirect sources" such as media reports and NGO accounts, some of them biased. Few facts were uncovered that were not already known. The mission did not meet the standards and objectivity expected in an inquiry for truth and justice. Although the Goldstone Report concluded that both Hamas and the IDF had probably violated the Geneva Conventions, it focused much more on the IDF than on Hamas and claimed that the IDF had targeted civilians. Two years later, after more evidence became available from the IDF and other sources, Judge Goldstone expressed major reservations about the conclusions of the UN fact-finding mission: "We know a lot more about what happened in the Gaza war...more than we did when I chaired...if that evidence had been available, the Goldstone Report would have been a different document" [Washington Post, 4/11/2011].

The whole controversy about the Geneva Conventions and the conduct of the war turned out to be "academic" in as much as neither Hamas nor the IDF, nor the NGOs and international community, took any steps to avert another war and to avoid civilian casualties in battle. In the 2014 round, Hamas had more and bigger rockets that could reach Tel Aviv, and had dug more tunnels that reached further into Israel; Israel had perfected the Iron Dome defense against rockets and shot down the lethal ones. But at the root, from a Geneva Convention' point of view and as far as civilian casualties are concerned, Gaza 2014 was a repeat of Gaza 2009 and Gaza 2012.

UN and Palestinian casualty figures claim (the UN gets its figures from the Palestinian Health Ministry) about 1900 killed, 83\% of whom were civilians, whereas the IDF counted about 900 deaths, 50\% civilians. These are not reliable figures. The Palestinians include the unarmed supporters of military operations (e.g. employees in the truck repair shop that makes rockets), casualties from their own misfired rockets and mortars, Palestinians they executed for "collaboration" and "treason," and armed policemen who participated in the fighting. The IDF analyzes the age and gender distribution of the casualties - not a random sample of the population - finds a preponderance of men of military age, notes whether the dead were labelled "martyrs" of the resistance and crosschecks body counts and identities with its own military reports. It comes up with half the Palestinian casualties and a lower proportion of civilians killed. The true numbers will not be known with any precision and not agreed upon even if more is known. Meanwhile, a propaganda war and accusations about casualties, civilian deaths, and war crimes continue without end in the absence of a trusted, non-partisan, objective, authoritative third party who can get at the truth. 


\section{CAN THE CYCLE OF GAZA WARS BE BROKEN?}

Hamas' strategy of rallying international opinion against Israel to end the occupation of the West bank and the blockade of Gaza by highlighting civilian casualties, suffering and ruins from the IDF in the Gaza wars has not been successful. The strategy is even less likely to succeed now that thousands of Arabs are being killed by other Arabs in sectarian wars all over the Middle East. The Israeli strategy of discrediting Hamas and associated Palestinian militants and rooting them out of Gaza by economic sanctions and military strikes has also not worked. If war does not benefit the adversaries, why does it nevertheless happen?

A major reason is that neither side pays the full costs of war. Humanitarian aid, international agencies, U.S., EU, Scandinavian and various Arab states pay for the reconstruction of Gaza- there are donor conferences and pledges to rebuild Gaza after every war and funds are provided; Iran provides new rockets and weapons, which are smuggled in through tunnels; part of the construction and other materials destined for civilian reconstruction by the humanitarian agencies are appropriated by Hamas for tunnels and warfare purposes; and Hamas recruits more young fighters in Gaza to replace the casualties it suffered. On the Israeli side, the United States supplies weapons, ammunition, technology and spare parts to the IDF; the American Jewish community donates money to compensate Israel for war costs and to fund more settlement expansion in the West Bank. Neither side pays the cost of their wars.

There are two issues in managing the Palestinian-Israel conflict: the short term issue of a cease fire and making it last, and the longer term issue of an Israel-Palestinian peace agreement which has several times failed in the past and keeps failing (e.g. the 2000 Camp David negotiations). The key idea is that neither Hamas, the Palestinians nor Israel are paying the full cost of the conflict. If they are compelled to pay a greater share of the cost, they will be more disposed to conciliate. Here I will mainly address the short term ceasefire issue, which, if dealt with, would contribute to resolving the long term peace issue.

For the cessation of attacks and war, a deal might be worked out in which Israel gradually lifts the blockade on dual-use goods and people travel in return for Hamas gradually turning over its weapons to an international commission and observer team who decommission the weapons and demilitarize Gaza. A precedent for such decommissioning exists: the demilitarization of the Provisional Irish Republican Army (IRA for short) in the Northern Ireland Peace Agreement of 1998 (PIRA, paragraph 3) by a neutral military 
commission made up of Scandinavian and Canadian officers, which took some months and experienced some setbacks but was in the end successful (Oberschall 2007). Call it the "weapons-for-the-end-of-the-blockade" deal. Egypt would have to shut down the Rafah tunnels to prevent arms smuggling, and at the surface crossings rigorous inspections of truckloads would have to take place, as now occur at the Israeli crossings. As in PIRA, prisoner releases and conditional amnesties to reintegrate fighters into civilian life might also be part of the ceasefire deal. Immediate reconstruction needs should be met unconditionally; such things as restoring electricity, water, building shelters for the homeless, and so on, under international monitoring.

Whether these measures can be accomplished with Hamas is a big question mark. The Gazans should at least know that for Israel the price of normalcy is demilitarization, and if Hamas rejects it, its priority is not normalcy for the Gaza population. On the more positive side, a plan for rebuilding the agriculture and manufacturing capacity lost since 2006 should be drawn up and funded by international donors, as a sequel to demilitarization. It would provide employment for those displaced by the end of the tunnel economy. Gaza will never become another Singapore or Hong Kong, but if peace prevails for a decade or two, it will become a moderately prosperous entity that gradually sheds its dependency on international welfare. The Palestinians are the most literate Arabs. There is plenty of talent that now emigrates which would stay. The "weapons-for-the-end-of-the-blockade" deal needs to be given a chance.

If the "weapons-for-the-end-of-the-blockade" deal is rejected by Hamas, unlike after past Gaza wars, the donors should not simply rebuild Gaza once again unconditionally; that is, should not enable a repeat war in one or two years. The situation is a classic "moral hazard": some innocent bystanders are going to be hurt, unavoidably, if the outside stakeholders change from enabling the conflict and violence to 'tough love' problem-solving behavior. If reconstruction funds are not provided, the Gaza bystanders will suffer first and most; Hamas will suffer least and last, but eventually it will be discredited. As Gaza stagnates and the peaceful West Bank prospers, this situation will become a credible alternative for the Gaza public. At some point, Hamas will lose the majority of Gazans and be unable to stay in power, even by force.

On the Israeli side, there is no chance that the U.S. government will stop equipping the IDF and provide other subsidies and aid, and the American Jewish community is going to continue offering financial support to Israel (Mearsheimer and Walt 2006). For instance, in September 2003, the U.S. reduced loan guarantees to Israel because of settlement expansion, but "the action was almost totally symbolic. It came the same day that Israel sold \$1.6 
billion bonds on Wall Street backed by a loan guarantee of repayment by the US government..." [NYT, 9/17/2003]. One measure that might be tried by the Palestinians to increase the cost of occupation and war for Israel is to charge rent for the Jewish settlements, military bases, settler-only roads and other land appropriated by Israel in the West Bank since 1967, pending a final peace settlement. The claim could be made retroactive to when the land was taken. The idea is that if is not possible to get rid of the occupation, the Palestinians should derive some benefit from it, and the cost to Israel should be a disincentive for more land annexation and settlements.

The Palestinians could press their case in both Israeli courts and, if rejected, which is likely, in international courts. Much land was and keeps being taken under the $19^{\text {th }}$ century Ottoman land law which no longer exists anywhere, or was appropriated by force, intimidation and fraud. According to David Shulman (2014), “...probably most jurists throughout the world, including many in Israel, regard all the settlements in the west Bank as illegal under international law, specifically under article 49 of the Fourth Geneva Convention .... and article 8 of the International Criminal Court Rome Statute of 1994." UN Resolution 242 which sets out the basic principles of a peace settlement, and the UN Charter, underscore "the inadmissibility of the acquisition of territory by war." Part of these rents could be earmarked for a buyout of the settlers' houses as an incentive for them to leave the settlements; part of it as compensation to Palestinian refugees in lieu of their right of return. This scheme may look far-fetched in the short run, but it is non-violent and it may resonate with international public opinion and law and become acceptable to many Israelis and Palestinians.

A political settlement between Israel and the Palestinians on 'stateness', security, boundaries, Jerusalem and the right to return is more preferable for ending the cycle of violence than continued episodic warfare in Gaza, but we know how difficult that has proven since Oslo. Both sides are deeply divided between moderates who want a negotiated peace and rejectionists who prefer to destroy the adversary: the divisions are Fatah-Hamas among Palestinians, and centrists-religious right among the Israelis. Neither side is a unified entity that can credibly enforce a peace agreement on its divided public, and neither side has an incentive to make a risky peace agreement. Israel will never make an agreement if its security is at risk.

The fundamental conflict over land and territory; i.e. who shall inhabit and control what part of Palestine, for the rejectionists of both sides, is driven by a religious mission to fulfill God's command. Religious fanaticism is a heavy obstacle to negotiating a peace. For Hamas, Palestine belongs to Allah and is the Holy Land of Islam, which amounts to Palestine minus Israel and the Jews. 
For the Israeli religious right and hypernationalists, the religious mission is "The Greater Land of Israel", which is Palestine without Palestinians (Press, 2010). To outside observers these futures are fantasy, but they are not to the true believers in both camps. Should the moderates strike a peace deal with each other (e.g. some version of the two state solution), Hamas might well precipitate civil strife, even civil war, against Fatah, and the same might happen among Israelis between the government and the religious right and the settlers. Even with a huge land swap it is estimated that at least two hundred thousand settlers would have to go back to Israel, many of whom would resist leaving (Thrall 2013). Removing settlers from the occupied territories by force might well lead to violent clashes between the settlers and their supporters who would flock to help them stay and the IDF, and might even precipitate mutinies in the IDF. Given the risk of fratricidal violence, the moderates on both sides may opt for the status quo.

This is not to say that what looks like irreconcilable conflict is always fated to persist. In the 1970's and 80's many observers expected South Africa to self-destruct in a huge race war, and yet the National Peace Accord of 1991 demilitarized the armed conflict and opened the way for a transition to majority rule by Africans. The Irish Republican Army (in its various incarnations) gave up armed struggle against Britain after seven decades and agreed to abide by the Northern Ireland Peace Agreement [Oberschall, pp. 218-220; pp. 170-178]. But the Palestinian-Israel conflict has not reached the stage of negotiations and compromise. Three years ago, the Middle East experts Hussein Agha and Robert Malley (2011) wrote an assessment of the Palestine situation which is still valid:" ...the peace process has been fueled by illusions. Bilateral negotiations have cultivated the pretense that Israel and Palestinians are equal parties when they are not. US involvement has fed Palestinian delusions and shielded Israel. The international community treatment of the PA has not brought Palestinians closer to statehood. It has deceived Palestinians about what to expect and corrupted their politics. Throwing money at the Palestinians has not ended the occupation but made it more palatable: it has reduced Israeli costs and created a Palestinian culture of dependency ..." The best one can hope for in the aftermath of the 2014 Gaza war is that a lasting ceasefire takes hold and, in conjunction with economic development initiatives, over time, moderates gain over rejectionists among both Palestinians and Israelis. 


\section{REFERENCES}

Agha, Hussein and Robert Malley (2011)Who's Afraid of the Palestinians New York Review of Books, 2/10/11

Anderson, Kenneth (2003) "Who Owns the Rules of War?" New York Times Magazine, 4/13

Deak, Istvan (2005) Hell and Liberation, New Republic, 8/15

Gutman Roy and David Rieff (1999) Crimes of War. What the Public Should Know, New York, Norton

Kaldor, Mary (2001) New Wars and Old, Stanford University Press

Levitt, Matthew (2006) Hamas. Politics, Charity, and Terrorism in the Service of Jihad, Yale University Press

Mearsheimer, John and Stephen Walt (2006), "The Israel Lobby and U.S. Foreign Policy" London Review of Books, $3 / 26$

Oberschall, Anthony (2007) Conflict and Peace Building in Divided Societies, Routledge

Press, Eyal (2010) "Israel's Holy Warriors” New York Review of Books, 4/29

Schulman, David (2014) "Occupation: the Finest Israeli Documentary" New York Review of Books, $5 / 22$

Thrall, Nathan (2013) "What Future for Israel?" New York Review of Books, 8/15 